\title{
Role of Eelgrass in the Coastal Filter of Contrasting Baltic Sea Environments
}

\author{
Eero Asmala ${ }^{1}$ (1) $\cdot$ Camilla Gustafsson $^{1} \cdot$ Dorte Krause-Jensen $^{2} \cdot$ Alf Norkko $^{1,3} \cdot$ Heather Reader $^{4}$ • Peter A. Staehr ${ }^{5}$. \\ Jacob Carstensen ${ }^{5}$
}

Received: 2 January 2019 /Revised: 27 June 2019 / Accepted: 17 July 2019 / Published online: 29 July 2019

(C) The Author(s) 2019

\begin{abstract}
Coastal ecosystems act as filters of nutrients from land to the open sea. We investigated the role of eelgrass (Zostera marina) metabolism in the coastal filter transforming nitrogen, phosphorus, and organic carbon. Field campaigns following identical methodologies were carried out at two contrasting coastal locations: the mesohaline and nutrient-rich Roskilde Fjord, Denmark, and the mesotrophic brackish Tvärminne archipelago, Finland. Over the 24-h in situ benthic incubations, we measured oxygen concentrations continuously and assessed changes in DOM characteristics and net fluxes of carbon, nitrogen, and phosphorus. Ecosystem metabolism modeled on the basis of the $\mathrm{O}_{2}$ data showed that the systems were either net heterotrophic (Roskilde Fjord; -1.6 and $2.4 \mathrm{~g} \mathrm{O}_{2} \mathrm{~m}^{-2}$ day $^{-1}$ in eelgrass meadow and bare sand, respectively) or had balanced primary production and respiration (Tvärminne; 0.0 and $0.2 \mathrm{~g} \mathrm{O}_{2} \mathrm{~m}^{-2}$ day $^{-1}$ ). Overall, initial nutrient stoichiometry was a key factor determining benthic-pelagic fluxes of nutrients, which exacerbated the deviations from Redfield ratios of $\mathrm{N}$ and $\mathrm{P}$, indicating an efficient use of the limiting nutrient. A net diel uptake of dissolved inorganic $\mathrm{N}$ was observed at both locations $\left(-2.3 \mu \mathrm{moll} l^{-1}\right.$ day $^{-1}$ in Roskilde Fjord and $-0.1 \mu \mathrm{mol}^{-1}$ day $^{-1}$ in Tvärminne). Despite minor changes in dissolved organic carbon concentrations during the incubations, a marked increase of fluorescent DOM was observed at both locations, suggesting rapid heterotrophic processing of the DOM pool. Our results underline that the biogeochemical role of eelgrass in the coastal filter is not inherent, but strongly dependent on the environmental conditions.
\end{abstract}

Keywords Benthic-pelagic coupling $\cdot$ Ecosystem metabolism $\cdot$ Nitrogen cycling $\cdot$ Dissolved organic matter $\cdot$ Seagrass $\cdot$ Sediment release

\section{Introduction}

Changes in land use and human activities during the last centuries have increased inputs of nitrogen and phosphorus to

Communicated by Masahiro Nakaoka

Electronic supplementary material The online version of this article (https://doi.org/10.1007/s12237-019-00615-0) contains supplementary material, which is available to authorized users.

Eero Asmala

eero.asmala@helsinki.fi

1 Tvärminne Zoological Station, University of Helsinki, Hanko, Finland

2 Department of Bioscience, Aarhus University, Silkeborg, Denmark

3 Baltic Sea Centre, Stockholm University, Stockholm, Sweden

4 Department of Chemistry, Memorial University of Newfoundland, St. John's, Canada

5 Department of Bioscience, Aarhus University, Roskilde, Denmark coastal environments multi-fold (Smil 2000; Galloway et al. 2008). These inputs have stimulated the autochthonous production of organic material by aquatic primary producers and subsequently increased eutrophication in coastal zones (Cloern 2001). Pelagic primary producers have mainly been responsible for these observed increases in production. Synchronously, inputs of allochthonous carbon from terrestrial systems have been increasing, leading to increased concentrations of organic matter, further exacerbating eutrophication (Nixon 1995). The Baltic Sea is widely affected by eutrophication, (Gustafsson et al. 2012), and the consequences of this large-scale phenomenon are evident: decreased water transparency, hypoxia, changes in benthic vegetation, and aquatic food webs (Bonsdorff et al. 1997; Karlson 2002; Carstensen et al. 2014). Further, eutrophication changes the biogeochemical cycling of nutrients in coastal environments (McGlathery et al. 2007; Conley et al. 2011). Management actions to reduce nutrient loads over the past decades are, however, slowly leading to improved ecosystem status (e.g., Riemann et al. 2016). Coastal ecosystems play an important role as a "coastal filter," 
reducing the anthropogenic impact on the marine environment further down the aquatic continuum from rivers to oceans by transforming, temporarily retaining or permanently removing nutrients originating from the catchment from the reach of aquatic organisms (Bouwman et al. 2013; Asmala et al. 2017, 2018b).

Benthic primary producers such as seagrasses play an important ecological role for the coastal filter as hotspots for production, storage, and export of organic carbon (Duarte and Krause-Jensen 2017). They efficiently retain carbon and nutrients in their biomass during the growth season and also support longer-term storage in the sediment, while also protecting the shores, stabilizing sediments, and promoting biodiversity in shallow coastal ecosystems (e.g., Hemminga and Duarte 2000; Fourqurean et al. 2012; Duarte et al. 2013). Furthermore, marine vegetation stimulates nitrogen cycling processes such as denitrification and anammox (Eyre et al. 2016; Reynolds et al. 2016; Zarnoch et al. 2017). Shallow coastal seafloors typically have a high cover of benthic macrophytes in the well-lit photic zone, where they can contribute significantly to gross primary production (McGlathery 2001; Gattuso et al. 2006; Öberg 2006). The relative importance of benthic versus pelagic primary producers in shallow coastal systems is largely a function of depth and water clarity (Staehr et al. 2018), the latter strongly linked to nutrient loading (Borum and Sand-Jensen 1996).

Seagrass meadows sustain high productivity in coastal ecosystems and modify their immediate environment by reducing wave action and water currents and enhancing the deposition of organic matter (Duarte et al. 2013). Part of the production of seagrass meadows is exported as particulate organic carbon, and a considerable proportion of the primary production is released as dissolved organic carbon (DOC) to surrounding waters (Duarte and Cebrián 1996; Barrón et al. 2014; Duarte and Krause-Jensen 2017). This seagrass-derived DOC is typically a highly bioavailable carbon source for heterotrophic bacteria (Ziegler and Benner 1999). Microbial processing of this autochthonous DOC changes its bulk chemical and optical characteristics rapidly, enabling the tracking of the extent of these processes within the system (Asmala et al. 2018a). In addition to direct benthic-pelagic fluxes of nutrients and organic carbon, seagrasses influence various other biogeochemical processes in the sediment, including oxygen dynamics, mineralization of organic matter, ammonification, and nitrification-denitrification (Caffrey and Kemp 1990, 1991; Marbà et al. 2006; Hemminga and Duarte 2000; Boström et al. 2014; Gustafsson and Norkko 2016; Staehr et al. 2018).

In this study, we focus on eelgrass, Zostera marina (L.), which is a widespread seagrass species in the Northern Hemisphere. Eelgrass is a key species in the Baltic Sea, forming an essential habitat for aquatic biodiversity. In the Baltic Sea, it occurs along a salinity gradient from fully marine areas (salinity $>30$ ) to low salinity waters $(<6$;
Boström et al. 2014). The salinity gradient in the Baltic Sea affects the functioning of eelgrass meadows, and for example, eelgrass biomass and productivity tend to be higher in areas with higher salinity and more nutrient-rich conditions (such as the Kattegat and Belt Sea) compared to the more brackish and oligotrophic parts of the Baltic Sea (Boström et al. 2014). Despite the seemingly similar habitat types, eelgrass meadows in different parts of the Baltic Sea experience different environmental drivers and thus may play a different role as coastal filters depending on the system. For instance, Danish eelgrass sediments store considerably more carbon compared to Finnish eelgrass sediments (Röhr et al. 2016).

This study builds partially on the work by Staehr et al. (2018), in which the diel oxygen method was used to document the role and seasonality of eelgrass as a key driver of spatial differences in ecosystem metabolism in an estuary (Roskilde Fjord, Denmark). However, the role of eelgrass in the coastal filter functioning may vary over environmental gradients (such as salinity and nutrient concentrations), occurring across different coastal systems. Resolving how the ecosystem metabolism of eelgrass communities varies along environmental gradients is important to better understand the overall role of eelgrass in transforming, retaining, and removing nutrients and organic matter as part of the coastal filter (sensu Asmala et al. 2017). Despite numerous studies on seagrass ecology, their role in different ecosystems remains uncertain due to the lack of comparative data using a common methodology. Thus, our aim here was to address this knowledge gap by comparing changes in colored dissolved organic matter (CDOM) characteristics and fluxes of dissolved and total nutrients, dissolved organic carbon (DOC), and oxygen associated with eelgrass beds in two contrasting coastal environments. More specifically, our objective was to resolve whether eelgrass meadows have a comparable functional role in terms of production and processing of organic carbon and nutrients in shallow coastal waters at contrasting sites within the Baltic Sea. This was investigated using identical methodology in the two habitats of the Baltic Sea and conducting the studies during the same time period. We hypothesized that the more optimal seagrass growth conditions at higher salinity and more nutrient-rich conditions (Denmark) would lead to higher production and processing of organic matter and nutrients than at lower salinity and more oligotrophic conditions (Finland).

\section{Material and Methods}

\section{Study Locations}

The two study locations are situated on the opposing sides of the Baltic Proper, the main basin of the Baltic Sea 
(Fig. 1). Roskilde Fjord and Tvärminne archipelago also represent different points on the two major gradients in the Baltic Sea: salinity and nutrient concentrations (Table 1). Roskilde Fjord has higher levels of salinity and nutrients, whereas Tvärminne is characterized by lower levels of salinity and nutrients. Roskilde Fjord is a $30 \mathrm{~km}$ long and shallow estuary, with a mean depth of $3 \mathrm{~m}$. Freshwater residence time in the system is long, on average 8 months in the inner part, where this study was carried out (KampNielsen 1992). Based on analyses of orthophotos, eelgrass meadows cover about $28 \mathrm{~km}^{2}$ of the seafloor in shallow waters ( $0-2.5 \mathrm{~m}$ depth) of Roskilde Fjord, corresponding to $45 \%$ of the total area of this depth interval (Ørberg et al. 2018). In the catchment, land use is dominated by agriculture (67\% of the area) resulting in high nutrient loading to Roskilde Fjord. The Tvärminne sampling location is located in the outer archipelago, a mixing region for several water masses originating from Karjaanjoki estuary, the open Gulf of Finland and deep water from the layers close to the permanent halocline (Niemi 1973). The catchment area is dominated by forests ( $46 \%$ of the area), and the many lakes (covering $11 \%$ of the area) increase the freshwater residence time within the catchment (Mattsson et al. 2005). Exact eelgrass coverage information for Tvärminne area is not available, but the estimated coverage for the whole Finnish coastline is approximately $30 \mathrm{~km}^{2}$ (Boström et al. 2014). A common feature of both systems is that they are subtidal and have a long freshwater residence time compared to the typical fast-flowing estuaries in boreal areas with strong freshwater influence from large rivers. Both experiment locations exhibit strong benthicpelagic coupling due to the shallow water depth.
Fig. 1 Map showing the sampling locations in Roskilde Fjord (DK) and in Tvärminne (FI)
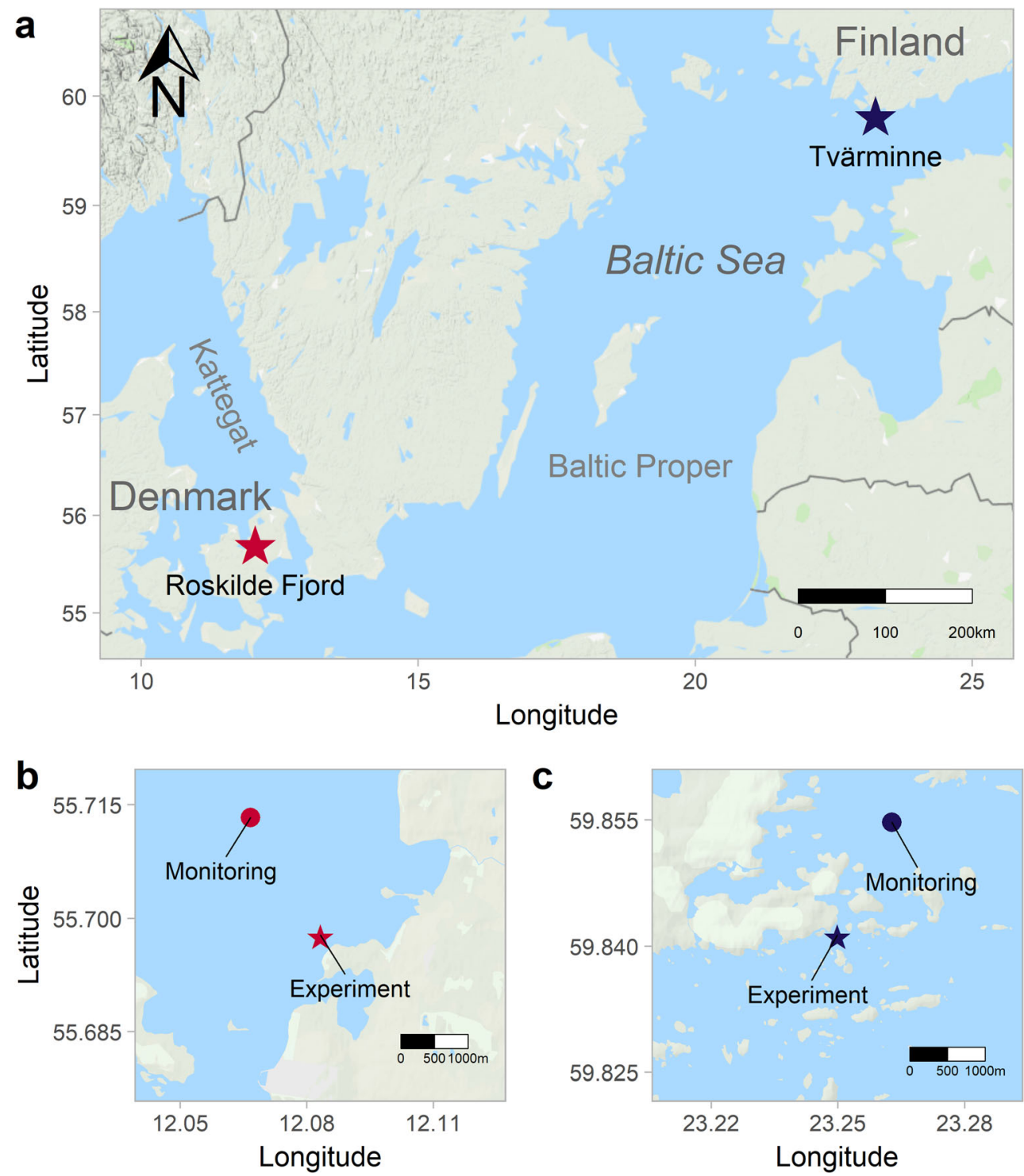
Table 1 Mean annual values (2012-2016) of key biogeochemical variables in the study systems. $\mathrm{TN}=$ total nitrogen, $\mathrm{TP}=$ total phosphorus, DIN = dissolved inorganic nitrogen, DIP = dissolved inorganic phosphorus, $\mathrm{Chl}=$ chlorophyll $\alpha, \mathrm{DOC}=$ dissolved organic carbon, $a_{(\mathrm{CDOM} 254)}=\mathrm{CDOM}$ absorption coefficient at $254 \mathrm{~nm}$. Data are means \pm SD. Minimum and maximum values of monthly means are also given

\begin{tabular}{|c|c|c|}
\hline Variable & Roskilde Fjord & Tvärminne \\
\hline Temperature $\left({ }^{\circ} \mathrm{C}\right)$ & $\begin{array}{l}11.1 \pm 6.5 \\
1.8(\mathrm{Feb})-19.2(\mathrm{Jul})\end{array}$ & $\begin{array}{l}8.8 \pm 6.0 \\
0.7 \text { (Feb)-16.8 (Aug) }\end{array}$ \\
\hline Salinity & $\begin{array}{l}13.3 \pm 1.3 \\
12.7 \text { (Mar)-14.0 (Oct) }\end{array}$ & $\begin{array}{l}5.7 \pm 0.4 \\
5.2(\mathrm{Feb})-6.2(\mathrm{Dec})\end{array}$ \\
\hline $\mathrm{TN}\left(\mu \mathrm{mol} 1^{-1}\right)$ & $\begin{array}{l}53.8 \pm 23 \\
32.7 \text { (May)-97.6 (Feb) }\end{array}$ & $\begin{array}{l}28.7 \pm 12 \\
22.3 \text { (Jun) } 43.3 \text { (Feb) }\end{array}$ \\
\hline $\mathrm{TP}\left(\mu \mathrm{mol} \mathrm{l}{ }^{-1}\right)$ & $\begin{array}{l}4.6 \pm 2.6 \\
0.9(\mathrm{Apr})-9.3(\mathrm{Aug})\end{array}$ & $\begin{array}{l}0.9 \pm 0.3 \\
0.6 \text { (Jun)-1.4 (Jan) }\end{array}$ \\
\hline $\operatorname{DIN}\left(\mu \mathrm{mol} \mathrm{l}^{-1}\right)$ & $\begin{array}{l}17.9 \pm 24.9 \\
0.8(\text { Jun })-70.8(\mathrm{Feb})\end{array}$ & $\begin{array}{l}6.1 \pm 9.4 \\
0.0(\mathrm{Jul})-19.5(\mathrm{Feb})\end{array}$ \\
\hline $\mathrm{DIP}\left(\mu \mathrm{mol} \mathrm{l}^{-1}\right)$ & $\begin{array}{l}3.7 \pm 2.5 \\
0.1 \text { (Apr)-7.6 (Aug) }\end{array}$ & $\begin{array}{l}0.4 \pm 0.3 \\
0.1 \text { (May) } 0.8 \text { (Dec) }\end{array}$ \\
\hline $\operatorname{Chl}\left(\mu \mathrm{g}^{-1}\right)$ & $\begin{array}{l}4.1 \pm 5.9 \\
1.2(\mathrm{Nov})-16.1 \text { (Mar) }\end{array}$ & $\begin{array}{l}4.7 \pm 7.9 \\
0.5 \text { (Jan)-18.1 (Apr) }\end{array}$ \\
\hline $\left.\operatorname{DOC}(\mu \mathrm{mol} \mathrm{l})^{-1}\right)$ & $\begin{array}{l}533 \pm 63^{1} \\
566.5 \text { (Jun)-485.5 (Dec) }\end{array}$ & $\begin{array}{l}421 \pm 92^{2} \\
\text { N/A }\end{array}$ \\
\hline$a_{(\mathrm{CDOM} 254)}\left(\mathrm{m}^{-1}\right)$ & $\begin{array}{l}34.8 \pm 2.3^{1} \\
32.1 \text { (May)-37.9 (Aug) }\end{array}$ & $\begin{array}{l}32.4 \pm 11.6^{2} \\
\text { N/A }\end{array}$ \\
\hline
\end{tabular}

${ }^{1}$ Data for 2014-2015, from Asmala et al. (2018b)

${ }^{2}$ Data for 2010-2011, from Asmala et al. (2016)

\section{Chamber Incubations}

To investigate the diel net fluxes between the water column and the benthic system, we deployed in situ chambers at both locations in August 2015 allowing us to incubate a section of the seafloor with its benthic community. Triplicate chamber incubations were conducted in two types of habitats, eelgrass meadow (eelgrass present), and bare bottom (eelgrass absent) for $24 \mathrm{~h}$. Incubations were carried out at depths of 2-3 $\mathrm{m}$ at both sites. The sediment type at both locations was sand, mostly coarse sand in Roskilde Fjord and medium sand in Tvärminne. The grain size reflects the exposure of the sites, as the Roskilde Fjord site is more exposed than the sheltered Tvärminne site. The eelgrass meadows in Tvärminne were clean from filamentous algae, but microphytobenthos was present at both sites. Additionally, in Roskilde Fjord, the bare bottom site had scattered small stones (5 to $10 \mathrm{~cm}$ in diameter) covered by filamentous algae.

The chambers consisted of transparent, gas impermeable plastic bags (diameter $19 \mathrm{~cm}$, height $42 \mathrm{~cm}$; average total volume 12 1) attached to a hard transparent plastic collar, which was secured firmly into the sediment with metal plugs. Similar benthic incubation chambers have frequently been used in benthic metabolism studies because the flexible plastic bag allows for natural water mixing within the chamber, which in turn minimizes the disturbance of the chamber interior during incubations (Hansen et al. 2000; Barrón et al. 2006; Gustafsson and Norkko 2016; Staehr et al. 2018). During the $24 \mathrm{~h}$ incubation, oxygen, temperature, and light were recorded every $10 \mathrm{~min}$ using oxygen and light loggers attached to a metal stick and placed approximately $30 \mathrm{~cm}$ above the seafloor inside each chamber. In addition, surface light intensity was also measured. Continuous measurements (every $10 \mathrm{~min}$ ) of dissolved oxygen (DO) and water temperature were made with miniDOT oxygen optode loggers (Precision Measurement Engineering, Vista, CA, USA). Continuous light measurements were made with $\mathrm{HOBO}$ pendant light loggers (Onset Computer Corporation, MA, USA). Water samples for nutrient and DOM analyses were drawn with a syringe through a hose inlet from the chambers at the beginning and at the end of the incubation. At each site, we calculated the diffuse light attenuation coefficient $\left(K_{\mathrm{PAR}}\right)$ as the linear slope between depth and the log of light intensity.

After the incubation was terminated, macroalgae was separated out, and all plant material within chambers was collected and sorted into living and decaying above- and belowground parts. To estimate the shoot density, eelgrass shoots were counted, and to measure biomass, the plant material was dried to constant dry weight $\left(60^{\circ} \mathrm{C}, 48 \mathrm{~h}\right)$. The above:belowground ratio was calculated based on the biomass of living shoots to rhizome and root biomass. For plant nutrient analyses, material was collected from fresh leaves, rhizomes, and roots and pooled across individuals to represent 3 subsamples.

\section{Diel Oxygen Method}

To investigate the importance of eelgrass and other benthic components for diel variations in oxygen concentrations and daily water column net fluxes, the selected in situ technique allowed us to incubate a section of the seafloor including the benthic community. Rates of system gross primary production (GPP), ecosystem respiration (R), and net ecosystem production (NEP) were determined from changes in the concentration of dissolved oxygen following the diel oxygen technique described in detail in Staehr et al. (2010). Oxygen measurements from Roskilde Fjord in this study are from Staehr et al. (2018). Briefly, we applied a similar inverse modeling approach (Hanson et al. 2008; Brighenti et al. 2015), which utilizes data on irradiance and temperature to model metabolic rates from high-frequency oxygen measurements. In the model, changes in dissolved oxygen over 10 min intervals $\left(\mathrm{DO}_{t}+\right.$ 1) were calculated as $\mathrm{DO}_{t+1}=\mathrm{DO}_{t}+\mathrm{GPP}_{t}-\mathrm{R}_{t}$ where $\mathrm{DO}_{t+1}$ and $\mathrm{DO}_{t}$ are the $\mathrm{DO}$ concentrations $\left(\mathrm{mg} \mathrm{l}^{-1}\right)$ at discrete times $t$ +1 and $t$ with 10 min resolution; $\mathrm{GPP}_{t}$ is the gross primary production at time $t ; R_{t}$ is the ecosystem respiration at time $t$. Net ecosystem production (NEP) was calculated using a light and temperature dependent model described by Brighenti 
et al. (2015). The approach models DO concentrations at every time step by estimation of daily values of three parameters defining the light-photosynthesis relationship. These daily light-photosynthesis parameters were then used to calculate hourly rates of NEP, GPP, and R inserting 10 min interval recordings of the available light at the incubation sites. See Staehr et al. (2018) for more details. Volumetric daily rates were finally converted to area-specific rates by multiplying rates with the volume of the incubation bags (12 1 on average) and dividing by the area $\left(0.028 \mathrm{~m}^{2}\right)$ of the incubation chambers. Respiration rates are displayed as negative values to facilitate rate comparison.

\section{Laboratory Analyses}

All water samples for analysis of the dissolved fraction were filtered through combusted $\left(450{ }^{\circ} \mathrm{C}, 4 \mathrm{~h}\right)$ glass fiber filters (nominal pore size $0.7 \mu \mathrm{m}$ ). Total nitrogen (TN) and total phosphorus (TP) were measured from unfiltered water samples, and total dissolved nitrogen (TDN), total dissolved phosphorus (TDP), ammonium, nitrite, nitrate (together referred to as DIN), and phosphate (DIP) were measured from filtered water samples. Nutrient concentrations were measured spectrophotometrically with an autoanalyzer (using the techniques described by Hansen and Koroleff (1999)). Dissolved organic nitrogen (DON) and dissolved organic phosphorus (DOP) were inferred by subtracting DIN and DIP from TDN and TDP, respectively. DOC was measured with a Shimadzu TOC- $\mathrm{V}_{\mathrm{CPH}}$ analyzer. The accuracy of measured DOC concentrations was controlled by analyzing a seawater reference standard provided by the CRM (consensus reference material, RSMAS, Miami, USA) program. Colored DOM (CDOM) absorption was measured using a Shimadzu 2401PC spectrophotometer with five $\mathrm{cm}$ quartz cuvette over the spectral range from 200 to $800 \mathrm{~nm}$ with $1 \mathrm{~nm}$ resolution. Ultrapure water was used as the blank for all samples. Excitation-emission matrices (EEMs) of fluorescent DOM (FDOM) were measured with a Varian Cary Eclipse fluorometer (Agilent). Processing of the EEMs was done using the eemR package for $\mathrm{R}$ software (Massicotte 2016). A blank sample of ultrapure water was subtracted from the EEMs, and the Rayleigh and Raman scattering bands were removed from the spectra after calibration. EEMs were calibrated by normalizing to the area under the Raman water scatter peak (excitation wavelength of $350 \mathrm{~nm}$ ) of an ultrapure water sample run on the same session as the samples and were corrected for inner filter effects with absorbance spectra (Murphy et al. 2010). For assessing the characteristics and the quality of the DOM pool, fluorescence peaks (Coble 1996) were calculated from the EEMs (peak C-humiclike; peak T-protein-like).
For the elemental and isotopic analysis of plant tissue, fresh eelgrass leaves, roots, and rhizomes were separated from the bulk biomass and dried to constant dry weight. The plant material was ground to a fine powder and the elemental concentrations of nitrogen (N) and carbon (C) as well as $\delta^{15} \mathrm{~N}$ and $\delta^{13} \mathrm{C}$ were analyzed using an elemental analyzer interfaced with an isotope ratio mass spectrometer (for Tvärminne samples: UC Davis Stable Isotope Facility, USA; for Roskilde samples: Thermo Fisher Scientific, at Aarhus University). The stable isotope signatures are reported in delta notation in relation to the international standards for carbon (primary standard: Vienna PeeDee Belemnite, secondary standards: acetanilide (Schimmelmann), sucrose, and N (air)). The $\delta$ notation reflects the ratio of the heavy to the light isotope in the sample $\left(R_{\text {sample }}\right)$ relative to that of the standard $\left(R_{\text {standard }}\right)$, i.e., $\delta_{\text {sample }}=1000\left[\left(R_{\text {sample }} / R_{\text {standard }}\right)-1\right]$.

\section{Monitoring Data and Statistical Analyses}

Monitoring data for surface (0-1 m depth) nutrient and chlorophyll concentrations (a proxy for phytoplankton biomass) were obtained for Roskilde Fjord from the Danish National Monitoring program NOVANA and for Tvärminne from the monitoring carried out by the Tvärminne Zoological Station and Finnish Meteorological Institute, which are also parts of national monitoring program. Nutrients (dissolved and total nitrogen and phosphorus; DIN, DIP, TN and TP, respectively) were analyzed in both monitoring programs with an autoanalyzer following similar methods by Hansen and Koroleff (1999), making direct comparison of these datasets possible. Further, chlorophyll was analyzed spectrofluorometrically from extracted filter samples in both monitoring programs. A 5-year period from 2012 to 2016 was selected to represent contemporary conditions in both systems. A non-parametric modeling approach, generalized additive models (GAM, Hastie and Tibshirani 1990), was used to test for the possible seasonality in these observations. Differences in nutrient fluxes between habitats and locations were investigated by means of non-parametric Kruskal-Wallis test. Significance threshold of $p<0.05$ was used. All statistical analyses were done using R software (R Core Team 2017).

\section{Results}

\section{Site Comparison}

Both systems showed strong seasonality, as water temperatures during the winter season were close to zero and summer maxima were around $15-20^{\circ} \mathrm{C}$ (Fig. S1). Salinity was higher and more constant on an annual scale in Roskilde Fjord compared to Tvärminne (Table 1; Fig. S1), indicating a lower degree of freshwater influence in Roskilde Fjord. Nutrient levels varied considerably between the two systems, resulting 
from differences in nutrient input from land and the exchange with the open sea. As Roskilde Fjord has a very limited connection with the open sea and receives relatively high nutrient inputs, nutrient levels were two to three times higher for nitrogen and five to ten times higher for phosphorus than in Tvärminne (Table 1). However, the phytoplankton biomass (indicated by chlorophyll concentration) was similar in both systems despite the large differences in apparent nutrient availability.

Both locations exhibited similar seasonal variation of dissolved inorganic nitrogen (DIN) (Fig. 2a), with high concentrations in winter which became rapidly depleted with the onset of the spring bloom in March-May. Dissolved inorganic phosphorus (DIP) is also depleted with the spring bloom in both systems but replenished during summer in Roskilde Fjord (Fig. 2c). The ratio of DIN to DIP reveals that the production in Tvärminne is potentially limited by DIN throughout most of the productive period, but the low concentrations of both DIN and DIP could also imply co-limitation of $\mathrm{N}$ and P (Tamminen and Andersen 2007). In Roskilde Fjord, the seasonal nutrient dynamics are more pronounced than in
Tvärminne, shifting from potential P-limitation in spring to potential N-limitation in summer and autumn. Variations in total nitrogen (TN) and phosphorus (TP) were less pronounced than the inorganic pools. TN and TP variabilities were higher in Roskilde Fjord, suggesting a strong coupling with the dynamics of the inorganic pools.

During the $24 \mathrm{~h}$ incubations, the maximum irradiance inside the incubation units was 1475 and $1335 \mu \mathrm{mol} \mathrm{m}^{-2} \mathrm{~s}^{-1}$ in Roskilde Fjord and Tvärminne, respectively. In Roskilde Fjord, the mean irradiance was $303 \mu \mathrm{mol} \mathrm{m}{ }^{-2} \mathrm{~s}^{-1}$ and in Tvärminne $475 \mu \mathrm{mol} \mathrm{m}{ }^{-2} \mathrm{~s}^{-1}$. The diffuse light attenuation coefficient $\left(K_{\mathrm{PAR}}\right)$ was $0.874 \mathrm{~m}^{-1}$ in Roskilde Fjord and $0.511 \mathrm{~m}^{-1}$ in Tvärminne. Average temperature during incubations was $20.4(20.2-21.0)$ and $13.2(12.4-14.7){ }^{\circ} \mathrm{C}$ in Roskilde Fjord and in Tvärminne, respectively.

\section{Initial Conditions}

Initial nutrient concentrations of the in situ experiments (Table 2) were comparable to the long-term mean values of late summer (Table 1; Fig. S1), highlighting the
Fig. 2 The observed concentrations of a DIN, b TN, c DIN, and $\mathbf{d}$ TP in the study locations during a five-year period 2012-2016. Molar N:P ratios of dissolved inorganic and total fractions are shown in $\mathbf{e}$ and $\mathbf{f}$. Seasonal cycles were estimated from the observations using a GAM approach (smoothed with cyclic cubic regression) with $95 \%$ confidence interval shown as shaded area. Potentially limiting levels of DIN and DIP $\left(2.0 \mu \mathrm{mol} ~^{-1}\right.$ and $0.2 \mu \mathrm{mol} 1^{-1}$, respectively) and $\mathrm{N}: \mathrm{P}$ ratio of 16 (Redfield 1963) are marked with a solid horizontal lines
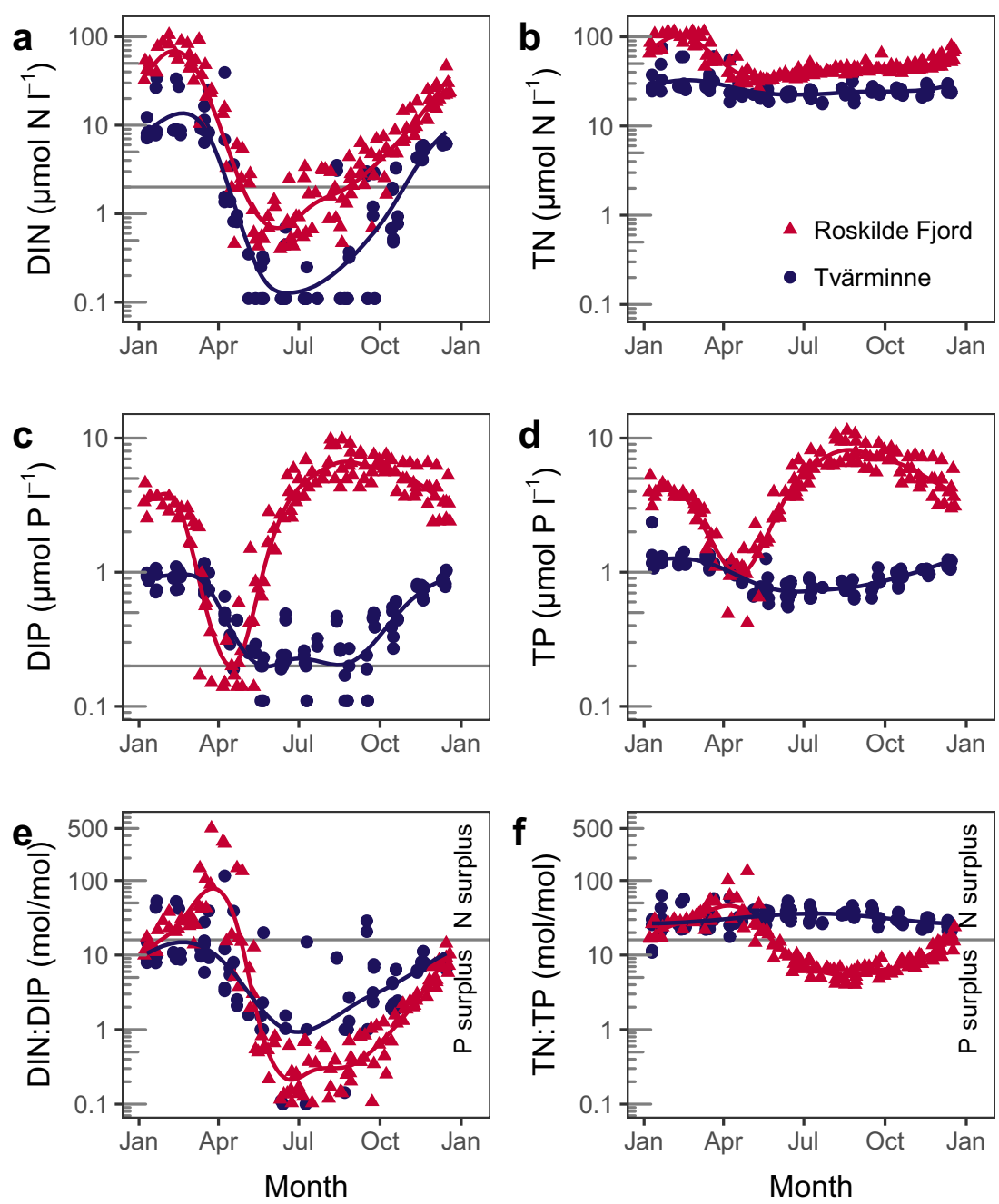
Table 2 Initial nutrient and DOM conditions in chamber incubations in August 2015 given as mean and standard deviation of the triplicate chambers. The difference between habitats at both locations was not significant for any variable $(p>0.05)$. All variables differ significantly between locations $(p<0.05)$

\begin{tabular}{|c|c|c|}
\hline Variable & Roskilde Fjord & Tvärminne \\
\hline $\mathrm{TN}\left(\mu \mathrm{mol} \mathrm{l}{ }^{-1}\right)$ & $47.3 \pm 5.8$ & $30.2 \pm 4.1$ \\
\hline $\mathrm{TP}\left(\mu \mathrm{mol} 1^{-1}\right)$ & $6.5 \pm 0.5$ & $0.80 \pm 0.3$ \\
\hline TN:TP ratio $\left(\mathrm{mol} \mathrm{mol}^{-1}\right)$ & $7.2 \pm 0.5$ & $40.7 \pm 10.6$ \\
\hline $\mathrm{DIN}\left(\mu \mathrm{mol} \mathrm{1} 1^{-1}\right)$ & $2.74 \pm 1.8$ & $0.54 \pm 0.4$ \\
\hline $\mathrm{DIP}\left(\mu \mathrm{mol} 1^{-1}\right)$ & $4.32 \pm 0.9$ & $0.08 \pm 0.0$ \\
\hline DIN:DIP ratio $\left(\mathrm{mol} \mathrm{mol}^{-1}\right)$ & $0.68 \pm 0.5$ & $6.69 \pm 5.9$ \\
\hline $\operatorname{DOC}\left(\mu \mathrm{mol} \mathrm{l}{ }^{-1}\right)$ & $509 \pm 43$ & $445 \pm 20$ \\
\hline $\mathrm{SUVA}_{254}\left(\mathrm{mg} \mathrm{C} \mathrm{m}^{-2}\right)$ & $2.69 \pm 0.2$ & $1.98 \pm 0.1$ \\
\hline$a_{\text {(CDOM254) }}\left(\mathrm{m}^{-1}\right)$ & $37.7 \pm 0.6$ & $24.6 \pm 0.6$ \\
\hline$a_{\text {(CDOM440) }}\left(\mathrm{m}^{-1}\right)$ & $1.21 \pm 0.1$ & $0.65 \pm 0.1$ \\
\hline Peak C (R.U.) & $0.34 \pm 0.0$ & $0.19 \pm 0.0$ \\
\hline Peak T (R.U.) & $0.16 \pm 0.0$ & $0.11 \pm 0.0$ \\
\hline UV Slope 275-295 $\left(\mu \mathrm{m}^{-1}\right)$ & $21.8 \pm 0.2$ & $24.0 \pm 0.40$ \\
\hline
\end{tabular}

differences in nutrient availability at the two locations. In Roskilde Fjord, nitrogen and phosphorus levels were higher than in Tvärminne for both inorganic and total $\mathrm{N}$ and P. N:P ratios were lower in Roskilde Fjord (and well below the Redfield ratio), indicating excess phosphorus. DOC concentrations were also higher in Roskilde Fjord, and this higher amount of DOM was more aromatic and more humic-like compared to Tvärminne (Table 2).

The eelgrass biomass in Roskilde Fjord was approximately three times higher than in Tvärminne (Table 3). Shoot densities were similar, but shoot weight and height were 2-3 times higher in Roskilde Fjord. The stable isotope signatures of the pooled eelgrass biomass also exhibited differences between locations, as eelgrass from Roskilde Fjord was more depleted in ${ }^{13} \mathrm{C}$ and more enriched in ${ }^{15} \mathrm{~N}$ than eelgrass from Tvärminne. Comparison of the biomass allocation between locations shows that a larger proportion of the total biomass is allocated to the below ground biomass compartment in Roskilde Fjord (Table 3). Almost $75 \%$ of the biomass was

Table 3 Characteristics of the eelgrass community at the study locations. Mean \pm standard deviation from three replicate chambers are given

\begin{tabular}{|c|c|c|c|}
\hline & Unit & Roskilde Fjord & Tvärminne \\
\hline \multicolumn{4}{|l|}{ Eelgrass biomass } \\
\hline Leaves & $\mathrm{g} \mathrm{m}^{-2}$ & $228.5 \pm 16.0$ & $86.9 \pm 18.2$ \\
\hline Rhizomes & $\mathrm{g} \mathrm{m}^{-2}$ & $94.1 \pm 23.8$ & $23.7 \pm 6.5$ \\
\hline Roots & $\mathrm{g} \mathrm{m}^{-2}$ & $32.6 \pm 4.9$ & $5.6 \pm 1.8$ \\
\hline $\begin{array}{l}\text { Total living } \\
\text { biomass }\end{array}$ & $\mathrm{g} \mathrm{m}^{-2}$ & $355 \pm 39.5$ & $116 \pm 22.7$ \\
\hline Decaying biomass & $\mathrm{g} \mathrm{m}^{-2}$ & $67.2 \pm 18.3$ & $21.0 \pm 3.4$ \\
\hline \multicolumn{4}{|l|}{ Biomass allocation } \\
\hline Leaves & $\%$ & $64.3 \pm 4.5$ & $74.8 \pm 15.7$ \\
\hline Rhizomes & $\%$ & $26.5 \pm 6.7$ & $20.4 \pm 5.6$ \\
\hline Roots & $\%$ & $9.2 \pm 1.4$ & $4.8 \pm 1.6$ \\
\hline $\begin{array}{l}\text { Above:belowground } \\
\text { ratio }\end{array}$ & & 1.8 & 3 \\
\hline $\begin{array}{l}\text { Eelgrass shoot } \\
\text { density }\end{array}$ & $\mathrm{m}^{-2}$ & $632 \pm 98.3$ & $507 \pm 135$ \\
\hline $\begin{array}{l}\text { Eelgrass shoot } \\
\text { weight }\end{array}$ & g shoot ${ }^{-1}$ & $0.60 \pm 0.15$ & $0.23 \pm 0.02$ \\
\hline Eelgrass shoot height & $\mathrm{cm}$ & $54.5 \pm 10.1$ & $27.1 \pm 1.6$ \\
\hline \multicolumn{4}{|c|}{$\mathrm{C}: \mathrm{N}$ ratio of biomass } \\
\hline Leaves & & $35.6 \pm 2.0$ & $19.7 \pm 1.5$ \\
\hline Rhizomes & & $35.2 \pm 4.1$ & $47.2 \pm 9.6$ \\
\hline Roots & & $22.5 \pm 1.8$ & $26.6 \pm 3.5$ \\
\hline$\delta^{13} \mathrm{C}$ & $\%$ & $-15.0 \pm 0.32$ & $-10.7 \pm 0.20$ \\
\hline$\delta^{15} \mathrm{~N}$ & $\%$ & $12.1 \pm 0.51$ & $7.42 \pm 0.19$ \\
\hline $\begin{array}{l}\text { Other macrophyte } \\
\text { biomass }\end{array}$ & & $\begin{array}{l}\text { Macroalgae constituted } 132.3 \pm 54.8 \mathrm{~g} \mathrm{~m}^{-2} \text { of the } \\
\text { macrophyte biomass in eelgrass incubations (ca. } 37 \% \text { ) } \\
\text { and } 76.0 \pm 20.3 \mathrm{~g} \mathrm{~m}^{-2} \text { in the non-eelgrass incubations. } \\
\text { No other angiosperms observed. }\end{array}$ & $\begin{array}{l}\text { Other angiosperms ( } P \text {. perfoliatus and } C \text {. demersum }) \\
\text { constituted ca. } 2 \% \text { of the seagrass biomass } \\
\left(2.7 \pm 0.9 \mathrm{~g} \mathrm{~m}^{-2}\right) \text {. No macroalgae recorded. }\end{array}$ \\
\hline
\end{tabular}


found in the leaves in Tvärminne, compared to $64 \%$ in Roskilde Fjord.

\section{Oxygen Fluxes}

Metabolic rates inferred from high frequency dissolved oxygen measurements showed higher gross primary production (GPP) in experimental units with eelgrass compared to bare sediments (Fig. 3a). In Roskilde Fjord, units with eelgrass had GPP of $3.5 \pm 0.7 \mathrm{~g} \mathrm{O}_{2} \mathrm{~m}^{-2}$ day $^{-1}$ on average, compared to $1.7 \pm 1.5 \mathrm{~g} \mathrm{O}_{2} \mathrm{~m}^{-2} \mathrm{day}^{-1}$ in units without eelgrass. In Tvärminne, GPP values in incubation units with and without eelgrass were $2.2 \pm 0.3$ and $0.5 \pm$ $0.1 \mathrm{~g} \mathrm{O}_{2} \mathrm{~m}^{-2}$ day $^{-1}$, respectively. Respiration (R) was also higher in units with eelgrass, the difference being more pronounced in Tvärminne (Fig. 3b). Net ecosystem production (NEP; GPP-R) was negative in Roskilde Fjord
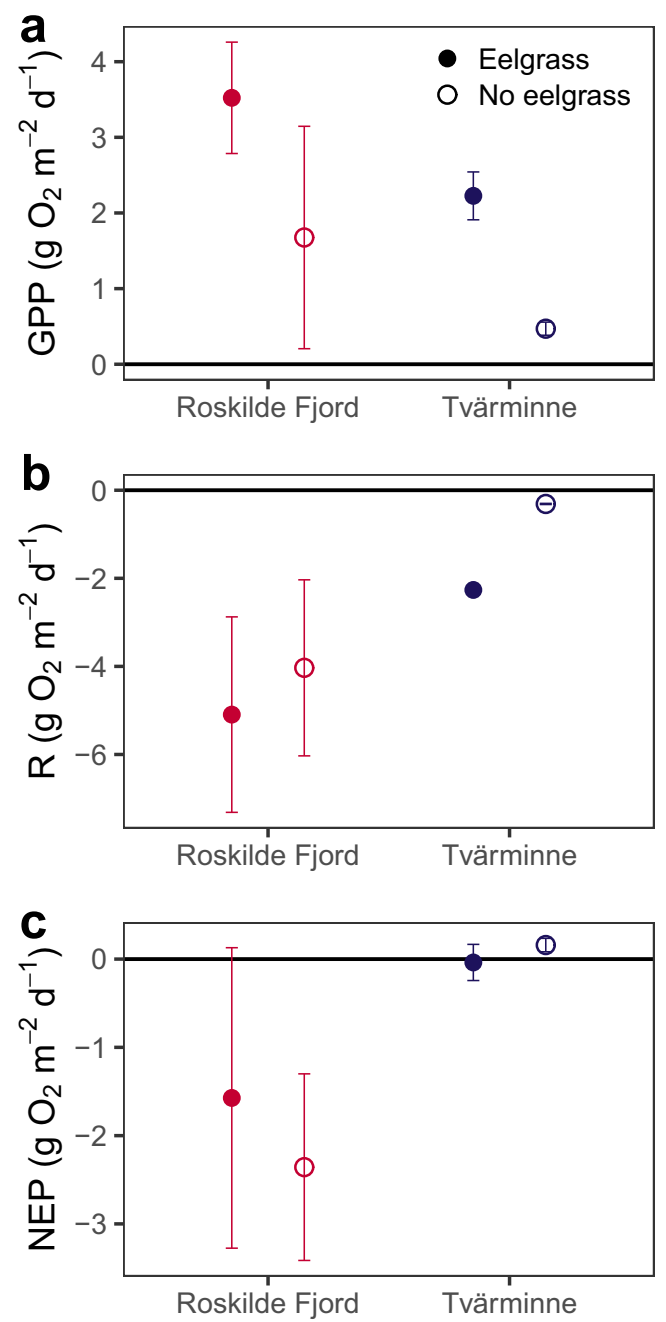

Fig. 3 Estimates of a gross primary production (GPP), b ecosystem respiration $(\mathrm{R})$ and $\mathbf{c}$ net ecosystem production (NEP) determined from continuous oxygen measurements during chamber incubations. Negative NEP values indicate $\mathrm{R}$ exceeding GPP. Points indicate the group mean value, and error bars indicate standard deviation $\left(-1.6 \pm 1.7\right.$ and $-2.4 \pm 1.1 \mathrm{~g} \mathrm{O}_{2} \mathrm{~m}^{-2}$ day $^{-1}$ in units with and without eelgrass, respectively), indicating net heterotrophy, whereas in Tvärminne production was practically balanced with respiration, on average $0.0 \pm 0.2$ and $0.2 \pm$ $0.1 \mathrm{~g} \mathrm{O}_{2} \mathrm{~m}^{-2}$ day $^{-1}$ in units with and without eelgrass, respectively (Fig. 3c). Areal net fluxes are presented in Table S4.

\section{Nutrient Fluxes}

Overall, the differences in nutrient fluxes among experimental units with or without eelgrass were minor in both locations. There was also considerable variation among experimental units (Fig. 4; Table S1), and many variables did not show significant differences between habitats (eelgrass present vs. absent) or locations (Roskilde Fjord vs. Tvärminne). Detailed results of the formal tests of difference between groups are in Tables $\mathrm{S} 2$ and S3. Decreases in DIN and increases in TN were observed at both locations $\left(-2.3\right.$ and $1.4 \mu \mathrm{mol} \mathrm{l}^{-1}$ day $^{-1}$ in Roskilde Fjord and -0.1 and $1.5 \mu \mathrm{mol} \mathrm{l}^{-1} \mathrm{day}^{-1}$ in Tvärminne, respectively). The benthic system in Roskilde Fjord seemed to act as a sink for inorganic nitrogen ($2.3 \mu \mathrm{mol} \mathrm{l}^{-1}$ day $^{-1}$ on average) and as a source of inorganic phosphorus $\left(0.3 \mu \mathrm{mol} \mathrm{l}^{-1}\right.$ day $\left.^{-1}\right)$. On the other hand, the presence of eelgrass had a significant influence on phosphorus fluxes in Tvärminne (Fig. $4 \mathrm{~b}$ and d). The eelgrass community acted as a source of DIP $\left(0.1 \mu \mathrm{mol} \mathrm{l}^{-1} \mathrm{day}^{-1}\right)$ and a sink for TP $\left(-0.2 \mu \mathrm{mol} \mathrm{l}^{-1}\right.$ day $\left.^{-1}\right)$, whereas fluxes from bare sediments (without eelgrass) showed the inverse pattern $(0.0$ and $0.1 \mu \mathrm{mol} \mathrm{l}^{-1}$ day $^{-1}$, respectively). Areal net fluxes are presented in Table S4.

\section{Changes in Nutrient Ratios}

We observed changes in nitrogen to phosphorus ratios in both inorganic and total fractions during the incubations (Fig. 5). In general, all incubations led to a further departure from the Redfield ratio, thus increasing the scarcity of the limiting nutrient. The inorganic nutrient ratio (DIN:DIP) decreased in both Roskilde Fjord and Tvärminne, on average by $-85 \%$ and $-28 \%$, respectively. Total nutrient ratio (TN:TP) decreased in Roskilde Fjord and increased in Tvärminne ($2.8 \%$ and $12 \%$ ). Eelgrass was not a major driver of change in Roskilde Fjord, but in Tvärminne, the presence of eelgrass resulted in larger changes in ratios of both nutrient fractions.

\section{DOC Fluxes and DOM Characteristics}

We observed relatively small net fluxes of DOC during incubations, except in eelgrass units in Roskilde Fjord, where the DOC concentration decreased by $19 \%$ ($98 \mathrm{mmol}^{-1}$ ) on average (Fig. 6; Table S1). CDOM absorption at $254 \mathrm{~nm}$ increased in Roskilde Fjord and decreased 
Fig. 4 Changes in a DIN, b DIP, c $\mathrm{TN}$, and $\mathbf{d}$ TP during 24-h in situ chamber incubations. Points show the mean value, and error bars mark the standard deviation. Positive values are benthic efflux, and negative values are benthic influx. Asterisk indicates significant differences $(p<0.05)$ between habitats (eelgrass/no eelgrass) for both locations separately

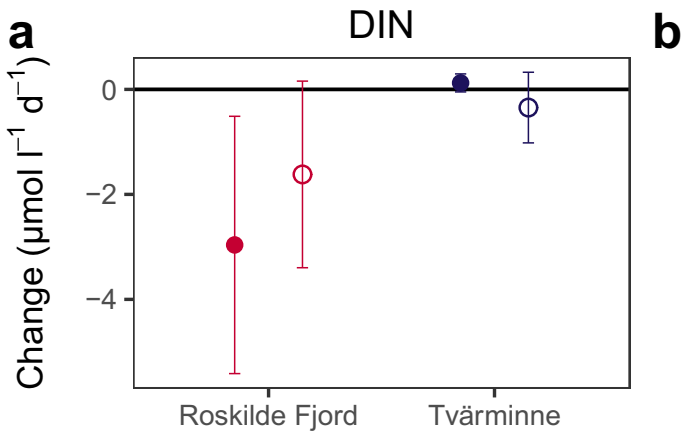

b
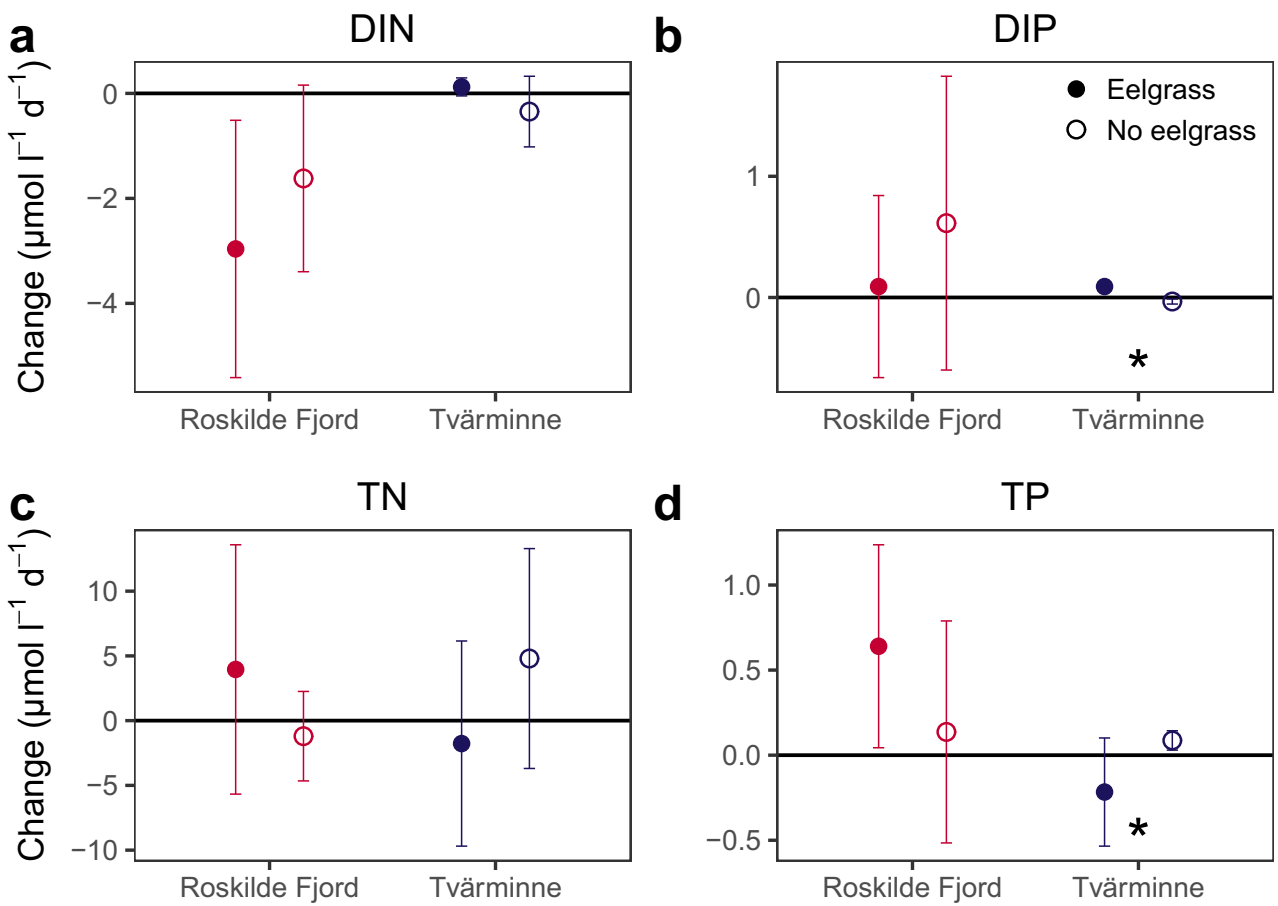

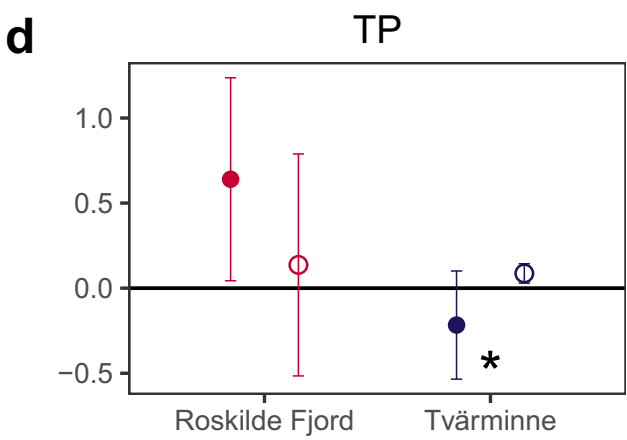

in Tvärminne, with no significant differences between habitats. Humic-like DOM (as indicated by fluorescence peak C) increased in all units, especially in incubations with eelgrass in Roskilde Fjord (7.3\% on average). Proteinlike DOM (peak T) increased considerably in units with eelgrass in both Roskilde Fjord and Tvärminne (on average $14 \%$ and $10 \%$, respectively).

\section{Discussion}

\section{Primary Producers and Ecosystem Metabolism}

We compared nutrient filter functioning of the same coastal ecosystem type in two contrasting environments over a diel cycle during peak biomass period. The results show that the role of submersed plants (as exemplified here by eelgrass) in coastal filter functioning is highly contextdependent and can be very different between coastal systems depending on the prevailing nutrient conditions and plant community characteristics. In Roskilde Fjord, the plant biomass was threefold higher than in Tvärminne, and a larger proportion of the biomass was allocated in roots and rhizomes (36\% and $25 \%$, respectively), probably reflecting the coarser sediment at the more exposed Roskilde site. Higher belowground biomass in Roskilde Fjord leads to higher potential for carbon sequestration by burial in deeper sediments (Röhr et al. 2016). Moreover, the much larger shoots in Roskilde as compared to Tvärminne may increase the role of the meadows
Fig. 5 Mean changes in N:P ratios during chamber incubations in $\mathbf{a}$ inorganic and $\mathbf{b}$ total nutrient fractions. Positive percentage values indicate an increase in the $\mathrm{N}: \mathrm{P}$ ratio, and negative values indicate decrease. Direction of the arrow shows the direction of the change between the start and end of the incubations. The relative mean change for each group is inserted in the plots. Colors indicate different sampling locations

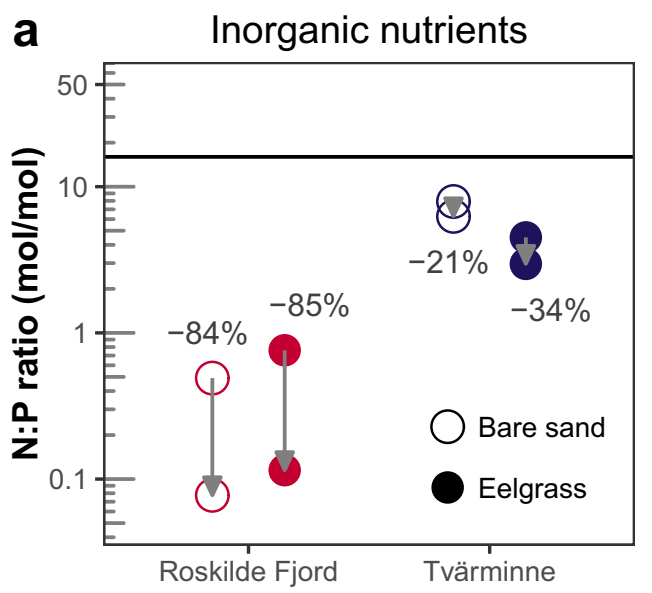

b

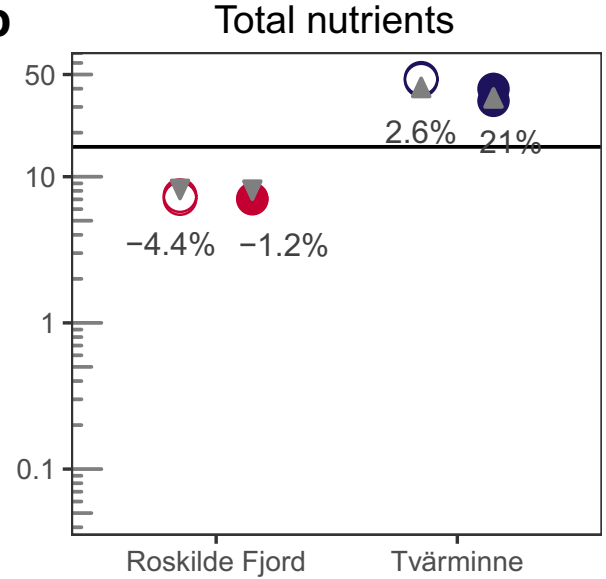


Fig. 6 Changes in a DOC concentration, b CDOM absorption at $254 \mathrm{~nm}$, c humiclike fluorescence (peak C), and d protein-like fluorescence (peak T) during 24-h in situ chamber incubations. Points indicate the group mean value, and error bars indicate standard deviation. Value of 0 indicates no change, positive values increase (source), and negative values decrease (sink). Asterisk indicates significant differences $(p<0.05)$ between habitats (eelgrass/no eelgrass) for both locations separately
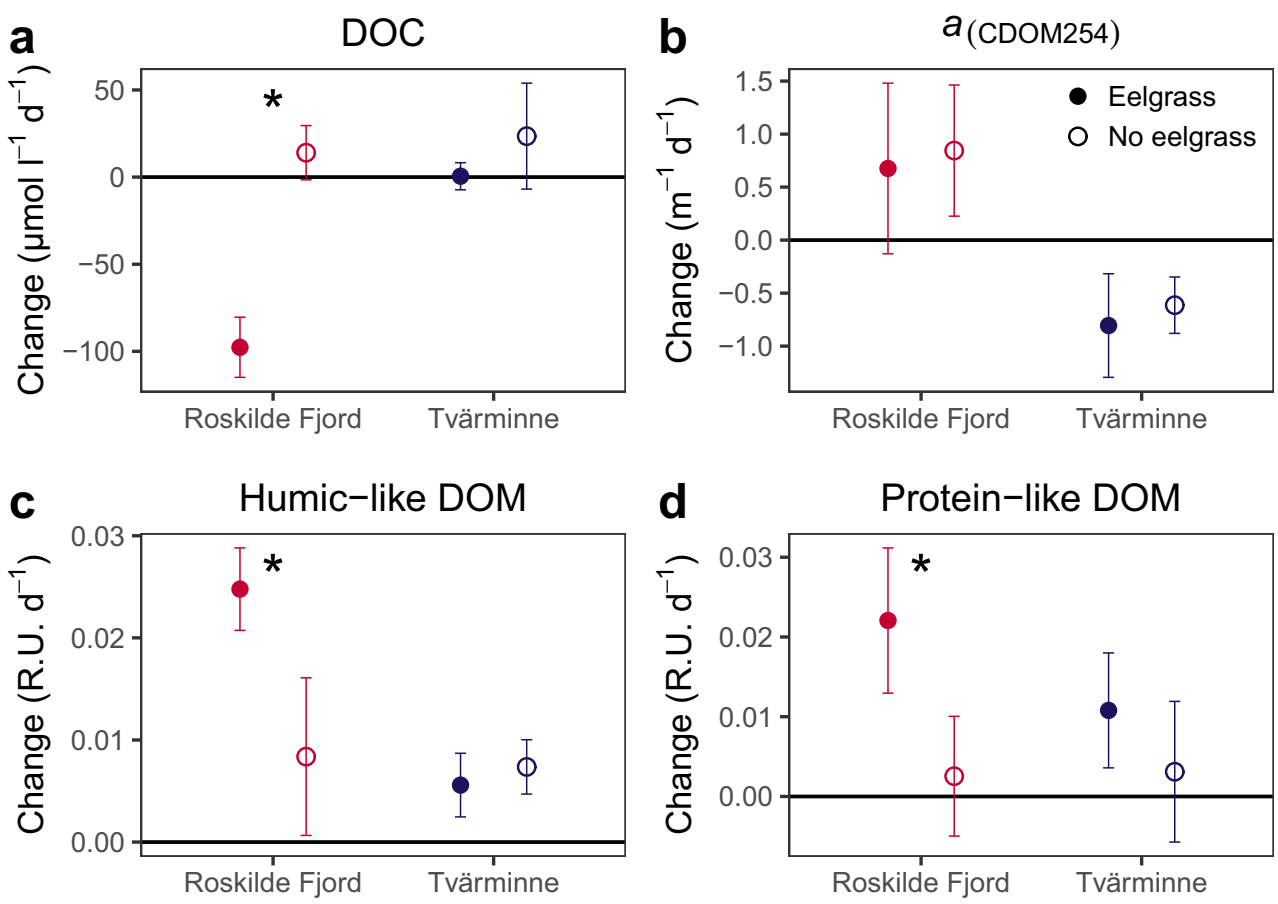

in retaining eelgrass detritus and particles from the water column and thereby store nutrients and organic carbon in the sediments.

At Tvärminne, the timing of the study coincided with peak eelgrass production per square meter, and the net production of the eelgrass community in Tvärminne of zero was slightly lower than in August the previous year at the same location $\left(0.4 \mathrm{~g} \mathrm{O}_{2} \mathrm{~m}^{-2}\right.$ day $^{-1}$; Gustafsson and Norkko 2016). In Danish eelgrass meadows, production tends to peak in June while biomass peaks in August/ September (Sand-Jensen 1975); so at Roskilde, the timing of the study coincided with peak annual biomass. Such latitudinal phenology is well-established for eelgrass communities (Clausen et al. 2014; Blok et al. 2018). Overall, there appears to be considerable differences in the ecosystem metabolism between the two locations, as Roskilde Fjord was highly heterotrophic during the campaign in mid-August, whereas the production and consumption were more or less balanced in Tvärminne.

As hypothesized, we measured the highest overall GPP in eelgrass incubations in Roskilde Fjord. Surprisingly, the incubations without eelgrass in Roskilde Fjord yielded almost as high GPP as eelgrass incubations in Tvärminne, reflecting a strong contribution of microphytobenthos, phytoplankton, and filamentous algae to primary productivity in Roskilde Fjord. Also, the higher temperature might contribute to the higher GPP and R in Roskilde Fjord. The recent improvements in water quality have decreased phytoplankton biomass and thus increased the light availability in Danish coastal waters, including Roskilde Fjord (Riemann et al. 2016), and this change has likely facilitated the high production potential of the benthic microphyte community (Sundbäck et al. 2000).

Differences between the locations were also reflected in the measured respiration; the larger eelgrass and apparent microphytobenthic biomass in Roskilde Fjord compared to Tvärminne resulted in almost fourfold larger respiration rates on average. The balance between total oxygen production (GPP) and consumption (respiration) was negative in Roskilde Fjord, indicating net heterotrophy at the time of the sampling (concurring with Staehr et al. 2017, 2018), whereas in Tvärminne, the production and consumption of oxygen were more or less balanced. In general, seagrass meadows tend to be net autotrophic but the net ecosystem metabolism of Zostera marina meadows globally is highly variable (Duarte et al. 2010). In a study by Gustafsson and Norkko (2016), eelgrass community in Tvärminne was autotrophic and thus had a higher production to respiration. However, the metabolism of eelgrass meadows is influenced by many factors, for example, meadow age, shoot density, amount of belowground biomass, and the occurrence of heterotrophic organisms, as well as high temperatures (Duarte et al. 2010; Rheuban et al. 2014). Thus, it is likely that the Danish site showed heterotrophy during the campaign due to high belowground biomass and warm temperatures, whereas earlier in the season (April-June), the system is autotrophic (Staehr et al. 2018). Despite lower variability in eelgrass biomass (11.1 and 19.6\% RSD in Roskilde Fjord and Tvärminne, respectively), variation in oxygen fluxes among experiment units was much higher in Roskilde Fjord, likely due to higher heterogeneity of the coarser sediment (Healey and Hovel 2004; Holland and Elmore 2008). 


\section{Nutrients and Organic Matter}

The monitoring data showed much higher nutrient levels in Roskilde Fjord, but phytoplankton biomass was similar in both systems. This can be explained with the higher grazing pressure by the highly active microzooplankton community and dense populations of bivalves in the shallow Roskilde Fjord (Møhlenberg 1995; Haraguchi et al. 2018). Thus, the overall species composition and food web configuration are also expected to be different in these systems, due to differences in hydromorphology, salinity, and nutrient availability, which might also reflect on the functioning of the benthic system. Higher nutrient concentrations in Roskilde Fjord are also reflected in DOC concentrations, as they are higher on the annual scale compared to Tvärminne, due to the high autochthonous production of organic matter and its accumulation as recalcitrant DOM after processing in the microbial loop (Asmala et al. 2018b).

The two study locations have different annual patterns regarding $\mathrm{N}$ and $\mathrm{P}$ availability (Fig. 2). Roskilde Fjord is potentially limited by phosphorus only during a short period in spring, and nitrogen limitation is more pronounced later during the growing season as active benthic remineralization quickly resupplies DIP stocks in summer-autumn (Staehr et al. 2017). In Tvärminne, on the other hand, both $\mathrm{N}$ and $\mathrm{P}$ become depleted in early summer and stay on a low level throughout the growing season. During the incubations, TN:TP of the water column was 41 in Tvärminne (as opposed to 7 in Roskilde), suggesting P-limitation in late summer. Also, the relatively high leaf $\mathrm{N}$ content and low $\mathrm{C} / \mathrm{N}$ ratio suggest that eelgrass in Tvärminne is not permanently $\mathrm{N}$ limited and likely supported by the nitrogen stocks in the sediment (Duarte 1990). However, nitrogen stocks in the sediment in Tvärminne are not necessarily high enough to sustain eelgrass nitrogen demand all the time, despite the relatively high leaf $\mathrm{N}$ content (Angove et al. 2018). The high $\mathrm{C} / \mathrm{N}$ ratio observed in rhizomes is likely the result of plants storing starch and other non-structural forms of carbohydrates produced during photosynthesis (Touchette and Burkholder 2000). The stable isotope composition of seagrasses reflects their nutrient source (Jones and Unsworth 2016) and the anthropogenic impact of the aquatic environment (Jones et al. 2018). The heavy influence of human activities around Roskilde Fjord is reflected by more ${ }^{15} \mathrm{~N}$-enriched eelgrass tissue (12\%o) in Roskilde Fjord than in Tvärminne (7\%o).

We observed large variation in fluxes not only of oxygen, nutrients, and carbon but also of DOM characteristics among the incubation units within locations, especially in Roskilde Fjord. This is likely the result of spatial sediment heterogeneity, which arises from physical characteristics of the benthic environment, such as sediment grain size, vertical layering, and patchiness, which can all vary considerably within small spatial scales (Holland and Elmore 2008). Heterogeneity of biological components, such as the distribution of vegetation, macrofauna, and even microbes, further adds to the complexity of the system (Healey and Hovel 2004; Gray 2002; Scala and Kerkhof 2000). Net nutrient fluxes during the incubations were in general similar between chambers with and without eelgrass, and only phosphorus fluxes in Tvärminne were significantly affected by the presence of eelgrass. In general, the $\mathrm{N}: \mathrm{P}$ stoichiometry in all incubations shifted further away from the Redfield ratio, thus exacerbating the relative depletion of the limiting nutrient. The pools of dissolved inorganic nutrients were more dynamic, as indicated by the larger changes during the incubations. The N:P ratio of the dissolved inorganic nutrients decreased over the diel cycle in both habitats in both Roskilde Fjord and Tvärminne, whereas the total N:P ratio decreased in Roskilde Fjord and increased in Tvärminne. This suggests that in Tvärminne, the pathways of total and dissolved inorganic nutrients are more disconnected than in Roskilde Fjord. In Roskilde Fjord, the changes in nutrient concentrations at the end of the incubations can be explained by the uptake of DIN, which is the growth-limiting nutrient in the system during late summer (Staehr et al. 2017). In Tvärminne, the uptake pattern of inorganic nutrients was not as obvious, since both DIN and DIP increased in eelgrass chambers and decreased in chambers without eelgrass. For total nutrients, this pattern was the opposite, suggesting that at Tvärminne, the eelgrass community acts as a source of dissolved inorganic nutrients and a sink for total nutrients. This observation may be explained by the direct release or facilitated enzymatic remineralization of inorganic nutrients and uptake of organic nutrients by eelgrass (Touchette and Burkholder 2000; Vonk et al. 2008).

A part of the primary production of eelgrass is exuded and leached to surrounding waters as dissolved organic carbon (DOC). However, eelgrass and their epiphytes exhibit heterotrophic uptake of DOC, which means that the DOC pool surrounding eelgrass communities is a result of a dynamic balance of production and consumption processes (Smith and Penhale 1980; Barrón et al. 2014). We observed only minor net changes in DOC concentrations in all other experimental units apart from the eelgrass units in Roskilde Fjord, where a considerable decrease in the DOC concentration occurred $(-18.7 \pm 2.2 \%$ on average). The eelgrass community appears to promote the remineralization activity of heterotrophic bacteria (Ziegler and Benner 1999). One possible mechanism for this is the so-called priming effect, where the introduction of labile carbon compounds (such as carbohydrates) enables utilization of other, more recalcitrant organic compounds (Guenet et al. 2010; Steen et al. 2016). This assumed coupling between eelgrass production and bacterial remineralization is supported by the marked increase in humic-like DOM in the units with the largest decrease in DOC concentration, which indicates the transformation of non-colored DOM to colored DOM (Shimotori et al. 2009; Asmala et al. 2018a). The metabolic response of the bacterial community to autochthonous DOM production is 
rapid; more than $50 \%$ of the DOC released by eelgrass can be remineralized on a daily basis (Ziegler and Benner 1999).

In conclusion, we found that the limiting nutrient $(\mathrm{N}$ in Roskilde Fjord and $\mathrm{P}$ in Tvärminne during the campaigns) plays a large role for the benthic-pelagic nutrient fluxes. The relative importance of eelgrass in the coastal filter functioning in terms of nutrient and organic matter cycling could not be unambiguously determined. Overall, in the nutrient-rich and more saline environment in Roskilde Fjord, we observed higher cycling rates for some nutrient (DIN, DIP, and TP) and OM fractions (DOC, humic-like DOM, and protein-like DOM). In Tvärminne, these deviations were more pronounced in eelgrass habitats compared to bare bottom. Further, we found considerable variability between replicate units, which underlines the challenges posed by the inherent heterogeneity of the benthic environment. At both locations, we observed that combined biogeochemical processes in the benthic environment exacerbate the deviations from Redfield ratios of nitrogen and phosphorus, indicating an efficient use of the limiting nutrient. Therefore, the limiting nutrient or nutrient stoichiometry should be considered as an important factor in shaping the functioning of the coastal filter, alongside nutrient or salinity levels. The observed rapid processing of the organic matter suggests that the changes in organic matter quality may be important while the changes in bulk quantity seem negligible. While seagrasses are, in general, very important for coastal biogeochemical processes, our results corroborate that the filtering effect is context-dependent.

Acknowledgments Open access funding provided by University of Helsinki. We are grateful for Lumi Haraguchi for the support in the lab. We also would like to thank Colin Stedmon from DTU Aqua for the DOC analysis and Janus Larsen from Aarhus University for support in field activities. We are thankful to Walter and Andrée de Nottbeck Foundation for supporting a workshop organized at Tvärminne Zoological Station.

Funding Information This study was supported by the BONUS COCOA project (grant agreement 2112932-1), funded jointly by the EU and Danish Research Council. EA was supported by the Academy of Finland (grant number 309748). CG was supported by the Walter and Andrée de Nottbeck Foundation and the Academy of Finland (grant number 295443).

Open Access This article is distributed under the terms of the Creative Commons Attribution 4.0 International License (http:// creativecommons.org/licenses/by/4.0/), which permits unrestricted use, distribution, and reproduction in any medium, provided you give appropriate credit to the original author(s) and the source, provide a link to the Creative Commons license, and indicate if changes were made.

\section{References}

Angove, C., A. Norkko, and C. Gustafsson. 2018. Assessing the efficiencies and challenges for nutrient uptake by aquatic plants. Journal of Experimental Marine Biology and Ecology 507: 23-30.
Asmala, E., H. Kaartokallio, J. Carstensen, and D.N. Thomas. 2016. Variation in riverine inputs affect dissolved organic matter characteristics throughout the estuarine gradient. Frontiers in Marine Science 2: 125.

Asmala, E., J. Carstensen, D.J. Conley, C.P. Slomp, J. Stadmark, and M. Voss. 2017. Efficiency of the coastal filter: nitrogen and phosphorus removal in the Baltic Sea. Limnology and Oceanography 62 (S1): S222-S238.

Asmala, E., L. Haraguchi, H.H. Jakobsen, P. Massicotte, and J. Carstensen. 2018a. Nutrient availability as major driver of phytoplankton-derived dissolved organic matter transformation in coastal environment. Biogeochemistry 137 (1-2): 93-104.

Asmala, E., L. Haraguchi, S. Markager, P. Massicotte, B. Riemann, P.A. Staehr, and J. Carstensen. 2018b. Eutrophication leads to accumulation of recalcitrant autochthonous organic matter in coastal environment. Global Biogeochemical Cycles 32 (11): 1673-1687.

Barrón, C., C.M. Duarte, M. Frankignoulle, and A.V. Borges. 2006. Organic carbon metabolism and carbonate dynamics in a Mediterranean seagrass (Posidonia oceanica), meadow. Estuaries and Coasts 29 (3): 417-426.

Barrón, C., E.T. Apostolaki, and C.M. Duarte. 2014. Dissolved organic carbon fluxes by seagrass meadows and macroalgal beds. Frontiers in Marine Science 1: 42.

Blok, S.E., B. Olesen, and D. Krause-Jensen. 2018. Life history events of eelgrass Zostera marina L. populations across gradients of latitude and temperature. Marine Ecology Progress Series 590: 79-93.

Bonsdorff, E., E. Blomqvist, J. Mattila, and A. Norkko. 1997. Coastal eutrophication: causes, consequences and perspectives in the archipelago areas of the northern Baltic Sea. Estuarine, Coastal and Shelf Science 44: 63-72.

Borum, J., and K. Sand-Jensen. 1996. Is total primary production in shallow coastal marine waters stimulated by nitrogen loading? Oikos 76 (2): 406-410.

Boström, C., S. Baden, A. Bockelmann, K. Dromph, S. Fredriksen, C. Gustafsson, et al. 2014. Distribution, structure and function of Nordic eelgrass (Zostera marina) ecosystems: implications for coastal management and conservation. Aquatic Conservation: Marine and Freshwater Ecosystems 24 (3): 410-434.

Bouwman, A., M. Bierkens, J. Griffioen, M. Hefting, J. Middelburg, H. Middelkoop, et al. 2013. Nutrient dynamics, transfer and retention along the aquatic continuum from land to ocean: towards integration of ecological and biogeochemical models. Biogeosciences 10 (1): 122.

Brighenti, L.S., P.A. Staehr, L.M. Gagliardi, L.P.M. Brandão, E.C. Elias, Nelson Azevedo Santos Teixeira de Mello, et al. 2015. Seasonal changes in metabolic rates of two tropical lakes in the Atlantic forest of Brazil. Ecosystems 18 (4): 589-604.

Caffrey, J.M., and W.M. Kemp. 1990. Nitrogen cycling in sediments with estuarine populations of Potamogeton perfoliatus and Zostera marina. Marine Ecology Progress Series 66: 147-160.

Caffrey, J., and W. Kemp. 1991. Seasonal and spatial patterns of oxygen production, respiration and root-rhizome release in Potamogeton perfoliatus L. and Zostera marina L. Aquatic Botany 40 (2): 109-128.

Carstensen, J., J.H. Andersen, B.G. Gustafsson, and D.J. Conley. 2014. Deoxygenation of the Baltic Sea during the last century. Proceedings of the National Academy of Sciences of the United States of America 111 (15): 5628-5633. https://doi.org/10.1073/ pnas.1323156111.

Clausen, K.K., D. Krause-Jensen, B. Olesen, and N. Marbà. 2014. Seasonality of eelgrass biomass across gradients in temperature and latitude. Marine Ecology Progress Series 506: 71-85.

Cloern, J.E. 2001. Our evolving conceptual model of the coastal eutrophication problem. Marine Ecology Progress Series 210: 223-253.

Coble, P.G. 1996. Characterization of marine and terrestrial DOM in seawater using excitation-emission matrix spectroscopy. Marine Chemistry 51 (4): 325-346. 
Conley, D.J., J. Carstensen, J. Aigars, P. Axe, E. Bonsdorff, T. Eremina, B.M. Haahti, C. Humborg, P. Jonsson, J. Kotta, C. Lännegren, U. Larsson, A. Maximov, M.R. Medina, E. Lysiak-Pastuszak, N. Remeikaitè-Nikienè, J. Walve, S. Wilhelms, and L. Zillén. 2011. Hypoxia is increasing in the coastal zone of the Baltic Sea. Environmental Science and Technology 45 (16): 6777-6783.

Duarte, C.M. 1990. "Seagrass nutrient content." Marine ecology progress series. Oldendorf 6, no. 2: 201-207

Duarte, C.M., and J. Cebrián. 1996. The fate of marine autotrophic production. Limnology and Oceanography 41 (8): 1758-1766.

Duarte, C.M., and D. Krause-Jensen. 2017. Export from seagrass meadows contributes to marine carbon sequestration. Frontiers in Marine Science 4: 13.

Duarte, C.M., N. Marbà, E. Gacia, J.W. Fourqurean, J. Beggins, C. Barrón, and E.T. Apostolaki. 2010. Seagrass community metabolism: assessing the carbon sink capacity of seagrass meadows. Global Biogeochemical Cycles 24 (4).

Duarte, C.M., H. Kennedy, N. Marbà, and I. Hendriks. 2013. Assessing the capacity of seagrass meadows for carbon burial: current limitations and future strategies. Ocean and Coastal Management 83: 32-38.

Eyre, B.D., D.T. Maher, and C. Sanders. 2016. The contribution of denitrification and burial to the nitrogen budgets of three geomorphically distinct Australian estuaries: importance of seagrass habitats. Limnology and Oceanography 61 (3): 1144-1156.

Fourqurean, J.W., C.M. Duarte, H. Kennedy, N. Marbà, M. Holmer, M.A. Mateo, E.T. Apostolaki, G.A. Kendrick, D. Krause-Jensen, K.J. McGlathery, and O. Serrano. 2012. Seagrass ecosystems as a globally significant carbon stock. Nature Geoscience 5 (7): 505-509.

Galloway, J.N., A.R. Townsend, J.W. Erisman, M. Bekunda, Z. Cai, J.R. Freney, et al. 2008. Transformation of the nitrogen cycle: recent trends, questions, and potential solutions. Science (New York, N.Y.) 320 (5878): 889-892. https://doi.org/10.1126/science.1136674.

Gattuso, J., B. Gentili, C.M. Duarte, J. Kleypas, J.J. Middelburg, and D. Antoine. 2006. Light availability in the coastal ocean: impact on the distribution of benthic photosynthetic organisms and contribution to primary production. Biogeosciences Discussions 3 (4): 895-959.

Gray, J.S. 2002. Species richness of marine soft sediments. Marine Ecology Progress Series 244: 285-297.

Guenet, B., M. Danger, L. Abbadie, and G. Lacroix. 2010. Priming effect: bridging the gap between terrestrial and aquatic ecology. Ecology 91 (10): 2850-2861.

Gustafsson, C., and A. Norkko. 2016. Not all plants are the same: exploring metabolism and nitrogen fluxes in a benthic community composed of different aquatic plant species. Limnology and Oceanography 61 (5): 1787-1799.

Gustafsson, B.G., F. Schenk, T. Blenckner, K. Eilola, H.M. Meier, B. Müller-Karulis, et al. 2012. Reconstructing the development of Baltic Sea eutrophication 1850-2006. Ambio 41 (6): 534-548.

Hansen, H.P., and F. Koroleff. 1999. Determination of nutrients. In Methods of Seawater Analysis, 159-228.

Hansen, J.W., A.U. Pedersen, J. Berntsen, I.S. Rønbøg, L.S. Hansen, and B.A. Lomstein. 2000. Photosynthesis, respiration, and nitrogen uptake by different compartments of a Zostera marina community. Aquatic Botany 66 (4): 281-295.

Hanson, P.C., S.R. Carpenter, N. Kimura, C. Wu, S.P. Cornelius, and T.K. Kratz. 2008. Evaluation of metabolism models for free-water dissolved oxygen methods in lakes. Limnology and Oceanography: Methods 6 (9): 454-465.

Haraguchi, L., H.H. Jakobsen, N. Lundholm, and J. Carstensen. 2018. Phytoplankton community dynamic: a driver for ciliate trophic strategies. Front.Mar.Sci 5: 272.

Hastie, T., and Tibshirani, R. 1990. Generalized additive models Wiley Online Library.

Healey, D., and K.A. Hovel. 2004. Seagrass bed patchiness: effects on epifaunal communities in San Diego bay, USA. Journal of Experimental Marine Biology and Ecology 313 (1): 155-174.
Hemminga, M.A., and C.M. Duarte. 2000. Seagrass ecology. Cambridge University Press.

Holland, K., and P. Elmore. 2008. A review of heterogeneous sediments in coastal environments. Earth-Science Reviews 89 (3-4): 116-134.

Jones, B.L., and R.K. Unsworth. 2016. The perilous state of seagrass in the British Isles. Royal Society Open Science 3 (1): 150596.

Jones, B.L., L.C. Cullen-Unsworth, and R.K. Unsworth. 2018. Tracking nitrogen source using $\delta 15 \mathrm{~N}$ reveals human and agricultural drivers of seagrass degradation across the British Isles. Frontiers in Plant Science 9: 133.

Kamp-Nielsen, L. 1992. Benithic-pelagic coupling of nutrient metabolism along an estuarine eutrophication gradient. Hydrobiologia 235 (1): 457-470.

Karlson, K. 2002. Temporal and spatial large-scale effects of eutrophication and oxygen deficiency on benthic fauna in Scandinavian and Baltic waters-a review. Oceanography and Marine Biology. Annual Review 40: 427-489.

Marbà, N., R. Santiago, E. Díaz-Almela, E. Álvarez, and C.M. Duarte. 2006. Seagrass (Posidonia oceanica) vertical growth as an early indicator of fish farm-derived stress. Estuarine, Coastal and Shelf Science 67 (3): 475-483.

Massicotte, P. 2016. eemR: tools for pre-processing emission-excitationmatrix (EEM) fluorescence data. $R$ Package Version 0.1, 4.

Mattsson, T., P. Kortelainen, and A. Räike. 2005. Export of DOM from boreal catchments: impacts of land use cover and climate. Biogeochemistry 76 (2): 373-394.

McGlathery, K.J. 2001. Macroalgal blooms contribute to the decline of seagrass in nutrient-enriched coastal waters. Journal of Phycology 37 (4): 453-456.

McGlathery, K.J., K. Sundbäck, and I.C. Anderson. 2007. Eutrophication in shallow coastal bays and lagoons: the role of plants in the coastal filter. Marine Ecology Progress Series 348: 1-18.

Møhlenberg, F. 1995. Regulating mechanisms of phytoplankton growth and biomass in a shallow estuary. Ophelia 42 (1): 239-256.

Murphy, K.R., K.D. Butler, R.G. Spencer, C.A. Stedmon, J.R. Boehme, and G.R. Aiken. 2010. Measurement of dissolved organic matter fluorescence in aquatic environments: an interlaboratory comparison. Environmental Science and Technology 44 (24): 9405-9412.

Niemi, A. 1973. Ecology of phytoplankton in the Tvärminne area, SW coast of Finland I. dynamics of hydrography, nutrients, chloporphyll a and phytoplankton.

Nixon, S.W. 1995. Coastal marine eutrophication: a definition, social causes, and future concerns. Ophelia 41 (1): 199-219.

Öberg, J. 2006. Primary production by macroalgae in kattegat, estimated from monitoring data, seafloor properties, and model simulations. Continental Shelf Research 26 (19): 2415-2432.

Ørberg, S. B., Groom, G. B., Kjeldgaard, A., Carstensen, J., Rasmussen, M. B., Clausen, P., et al. 2018. Kortlægning af ålegræsenge med ortofotos:-muligheder og begrænsninger.

R Core Team. (2017). R: A language and environment for statistical computing.

Redfield, A.C. 1963. The influence of organisms on the composition of seawater. The Sea 2: 26-77.

Reynolds, L.K., M. Waycott, K.J. McGlathery, and R.J. Orth. 2016. Ecosystem services returned through seagrass restoration. Restoration Ecology 24 (5): 583-588.

Rheuban, J.E., P. Berg, and K.J. McGlathery. 2014. Ecosystem metabolism along a colonization gradient of eelgrass (Zostera marina) measured by eddy correlation. Limnology and Oceanography 59 (4): $1376-1387$.

Riemann, B., J. Carstensen, K. Dahl, H. Fossing, J.W. Hansen, H.H. Jakobsen, A.B. Josefson, D. Krause-Jensen, S. Markager, P.A. Stæhr, K. Timmermann, J. Windolf, and J.H. Andersen. 2016. Recovery of Danish coastal ecosystems after reductions in nutrient loading: a holistic ecosystem approach. Estuaries and Coasts 39 (1): 82-97. 
Röhr, M.E., C. Boström, P. Canal-Vergés, and M. Holmer. 2016. Blue carbon stocks in Baltic Sea eelgrass (Zostera marina) meadows. Biogeosciences 13 (22): 6139-6153.

Sand-Jensen, K. 1975. Biomass, net production and growth dynamics in an eelgrass (Zostera marina L.) population in Vellerup Vig, Denmark. Ophelia 14 (1-2): 185-201.

Scala, D.J., and L.J. Kerkhof. 2000. Horizontal heterogeneity of denitrifying bacterial communities in marine sediments by terminal restriction fragment length polymorphism analysis. Applied and Environmental Microbiology 66 (5): 1980-1986.

Shimotori, K., Y. Omori, and T. Hama. 2009. Bacterial production of marine humic-like fluorescent dissolved organic matter and its biogeochemical importance. Aquatic Microbial Ecology 58 (1): 55-66.

Smil, V. 2000. Phosphorus in the environment: natural flows and human interferences. Annual Review of Energy and the Environment 25 (1): 53-88.

Smith, W.O., Jr., and P.A. Penhale. 1980. The heterotrophic uptake of dissolved organic carbon by eelgrass (Zostera marina L.) and its epiphytes. Journal of Experimental Marine Biology and Ecology 48 (3): 233-242.

Staehr, P.A., D. Bade, Van de Bogert, C. Matthew, G.R. Koch, C. Williamson, P. Hanson, et al. 2010. Lake metabolism and the diel oxygen technique: state of the science. Limnology and Oceanography: Methods 8 (11): 628-644.

Staehr, P.A., J. Testa, and J. Carstensen. 2017. Decadal changes in water quality and net productivity of a shallow Danish estuary following significant nutrient reductions. Estuaries and Coasts 40 (1): 63-79.

Staehr, P.A., E. Asmala, J. Carstensen, D. Krause-Jensen, and H. Reader. 2018. Ecosystem metabolism of benthic and pelagic zones of a shallow productive estuary: spatio-temporal variability. Marine Ecology Progress Series 601: 15-32.

Steen, A.D., L.N. Quigley, and A. Buchan. 2016. Evidence for the priming effect in a planktonic estuarine microbial community. Frontiers in Marine Science 3: 6.

Sundbäck, K., A. Miles, and E. Göransson. 2000. Nitrogen fluxes, denitrification and the role of microphytobenthos in microtidal shallowwater sediments: an annual study. Marine Ecology Progress Series 200: 59-76.

Tamminen, T., and T. Andersen. 2007. Seasonal phytoplankton nutrient limitation patterns as revealed by bioassays over Baltic Sea gradients of salinity and eutrophication. Marine Ecology Progress Series 340: 121-138.

Touchette, B.W., and J.M. Burkholder. 2000. Review of nitrogen and phosphorus metabolism in seagrasses. Journal of Experimental Marine Biology and Ecology 250 (1-2): 133-167.

Vonk, J.A., J.J. Middelburg, J. Stapel, and T.J. Bouma. 2008. Dissolved organic nitrogen uptake by seagrasses. Limnology and Oceanography 53 (2): 542-548.

Zarnoch, C.B., T.J. Hoellein, B.T. Furman, and B.J. Peterson. 2017. Eelgrass meadows, zostera marina (L.), facilitate the ecosystem service of nitrogen removal during simulated nutrient pulses in Shinnecock bay, New York, USA. Marine Pollution Bulletin 124 (1): $376-387$.

Ziegler, S., and R. Benner. 1999. Dissolved organic carbon cycling in a subtropical seagrass-dominated lagoon. Marine Ecology Progress Series 180: 149-160. 